\title{
WILKINSON V DOWNTON AFTER RHODES AND ITS FUTURE VIABILITY IN NEW ZEALAND
}

\author{
Pita Roycroft ${ }^{*}$
}

\begin{abstract}
This article analyses the tort in Wilkinson v Downton, commonly referred to as intentional infliction of emotional distress, in light of the United Kingdom Supreme Court's decision in Rhodes v OPO. After considering the three base elements of the Rhodes Court's newly reformulated tort, and giving a brief introduction to the New Zealand equivalent, the article suggests the law in this area is in need of further clarification and reform. The Rhodes formulation, while useful, does not go far enough in securing a viable future for the tort in light of the developments in negligence and privacy. The article justifies the tort's independence and suggests reforms to its elements in this respect. In particular, it concludes that the conduct element ought to be based on a "reasonable target" test, and the consequence element ought to be modified to allow recovery for damage amounting to severe emotional distress outside the range of ordinary human experience.
\end{abstract}

\section{INTRODUCTION}

In 1897, a man told a woman a false tale that her husband had been horribly bashed up at the races. ${ }^{1}$ She suffered from severe distress, nausea and her hair turned white. In 1922, a man approached a house at night and threatened the occupier that he would burn him out. ${ }^{2}$ The occupier's wife suffered a violent nervous shock and a miscarriage. In 1993, an extreme zombie splatter film featured a family burial plot in the background. ${ }^{3}$ A family member was shocked and deeply disturbed. Most recently, in 2015, a father wrote a book about himself, describing the horrors of his past, and dedicated it to his son. It was alleged the son would suffer from psychiatric illness if he read the book. ${ }^{4}$ The victims in

\footnotetext{
* Submitted as part of the LLB(Hons) programme at Victoria University of Wellington. The author wishes to thank his supervisor, Professor Bill Atkin, for his wisdom and support. All errors are, of course, my own.

1 Wilkinson v Downton [1897] 2 QB 57.

2 Stevenson v Basham [1922] NZLR 225 (SC).

3 Bradley $v$ Wingnut Films Ltd [1993] 1 NZLR 415 (HC).

4 Rhodes $v$ OPO [2015] UKSC 32, [2016] AC 219.
} 
all four scenarios brought proceedings to recover for, or prevent, emotional harm. ${ }^{5}$ Should they have been successful in doing so? The tort governing this area has been conceptually uncertain since 1897 , but that changed in 2015 .

This article analyses the Wilkinson $v$ Downton tort, occasionally referred to as intentional infliction of emotional distress (IIED). ${ }^{6}$ In light of the United Kingdom Supreme Court's decision in Rhodes $v O P O,{ }^{7}$ the primary focus is an evaluation of the tort's future viability in New Zealand. The article compares the approaches of cognate jurisdictions and proposes that, while Rhodes represents the best formulation so far, further reforms should be adopted if the tort is to be a useful cause of action, independent of the torts of negligence and privacy. For example, recovery should be allowed for severe emotional distress not amounting to a recognisable psychiatric illness. ${ }^{8}$ Issues concerning IIED's impact on freedom of expression, or the relevance of statutory causes of action under the accident compensation scheme, ${ }^{9}$ or harassment legislation (such as the Harmful Digital Communications Act 2015), fall outside the scope of the article.

\section{WILKINSON v DOWNTON}

Wilkinson was the unfortunate victim of a misconceived practical joke played on her by Downton. Believing it would be harmless banter, Downton announced at the Albion public house that Wilkinson's husband had broken both his legs in an accident and she was to "go at once with a cab and some pillows to fetch him home". ${ }^{10}$ The statement was false. Wilkinson, believing it to be true, suffered severe shock causing her weeks of physical and mental suffering.

Wright $\mathrm{J}$ was faced with a choice: deny Wilkinson recovery for lack of a cause of action, or fashion a new intentional tort based on indirectly inflicted physical and emotional suffering. Fortunately for Wilkinson, Wright $\mathbf{J}$ formulated a new tort, identifying the claimant's protected interest as her "legal right to personal safety". ${ }^{11}$ The tort required a defendant to have "wilfully done an act calculated to cause physical harm" which in fact "caused physical harm". ${ }^{2}$ Even if there was no subjective

5 In Rhodes the proceedings were brought on the victim's behalf.

6 The tort is commonly known as the rule in Wilkinson $v$ Downton but it has many other names. This article refers to the tort as "intentional infliction of emotional distress" (IIED) but this might be misleading with regards to the traditional formulation of the tort which required more than intentionally inflicted distress as a consequence to be actionable.

7 Rhodes, above n 4.

8 See Part V(C).

9 See Accident Compensation Act 2001.

10 Wilkinson, above $\mathrm{n} 1$, at 57.

11 At 59.

12 At 58-59. 
intention to cause harm, intention could be imputed as a matter of law if the consequences were so likely a result of the defendant's conduct that it could not reasonably be said that they were not intended. ${ }^{13}$ Wright $\mathrm{J}$ then held that the result was not too remote, on the basis that "the connection between the cause and the effect [was] sufficiently close and complete". ${ }^{14}$

Wright J's language, and in particular the odd mix of legal elements which would today be regarded as an illegitimate merging of intentional and negligence-based torts, ${ }^{15}$ gave rise to decades of confusion as to what the tort actually was. Some suggested it was a precursor to modern negligence; ${ }^{16}$ others thought it was an intentional tort but its indirect nature meant it was distinguishable from the traditional torts of trespass to the person and therefore could legitimately mix elements from both. ${ }^{17}$ In 2015, the United Kingdom Supreme Court quelled much of the confusion in Rhodes.

\section{RHODES v OPO}

Lord Hoffmann's judgment in Wainwright $v$ Home Office heralded the potential demise of the Wilkinson action. ${ }^{18} \mathrm{He}$ reasoned the tort had "no leading role in the modern law" given its inability to compensate for mere distress and the growth of the tort of negligence. ${ }^{19}$ However, Lord Hoffmann's judgment was wrong in this respect, and no more than an "interesting reconstruction [that showed] the pitfalls of interpreting a decision ... without a full understanding of jurisprudence and common legal terminology of the earlier period". ${ }^{20}$

\section{A The Facts}

The claimant in Rhodes, a 12-year old boy known only as OPO, had proceedings brought on his behalf by his mother and godfather seeking to restrain publication of a book by the claimant's father, James Rhodes. The book, entitled Instrumental, is a vivid account of the abuse suffered by Rhodes

13 At 59

14 At 59

15 See Mark Lunney "Practical Joking and its Penalty: Wilkinson v Downton in Context" (2002) 10 Tort L Rev 168 at $183-184$

16 See Wainwright v Home Office [2003] UKHL 53, [2004] 2 AC 406.

17 See Bradley, above n 3. See also Carrier v Bonham [2001] QCA 234, [2002] 1 Qd R 474 at [26] per McPherson JA.

18 Wainwright, above n 16.

19 At [41].

20 Rhodes, above n 4, at [62]. 
when he was young. Instrumental was dedicated in part to OPO. It was alleged that publication would constitute IIED (referred to in Rhodes as intentionally causing physical or psychological harm). ${ }^{21}$

At first instance, the application for an interim injunction against publication pending trial was struck out. ${ }^{22}$ Bean J held there was no duty of care for an action in negligence and that Wilkinson did not extend beyond false or threatening words. ${ }^{23}$ There was also no action for misuse of private information. ${ }^{24}$ The Court of Appeal, reversing the High Court decision in part, found for OPO and issued an interim injunction restraining certain parts of the book from being published. ${ }^{25}$ Arden LJ, giving the leading judgment, held Wilkinson was not limited to false or intimidating acts or statements,${ }^{26}$ but they must be unjustified. ${ }^{27}$ She held that publication of certain passages in the book and its dedication to the claimant was unjustified, and that the necessary intent could be imputed to the defendant. ${ }^{28}$

Rhodes appealed to the Supreme Court. The question before that Court concerned the proper scope of Wilkinson in modern law, and whether it could ever be used to prevent a person from publishing true information about themselves. ${ }^{29}$ The Court held for the appellant on the basis that two of the three major elements of the reformulated tort had not been made out. ${ }^{30}$

\section{B The Rhodes Elements}

The Rhodes Court affirmed the existence of the tort, clarified its purpose and reformulated its elements. The first joint reasons, given by Lady Hale and Lord Toulson, ${ }^{31}$ differed slightly from the second joint reasons given by Lord Neuberger. ${ }^{32}$ The Court agreed on three basic elements: conduct, mental and consequence.

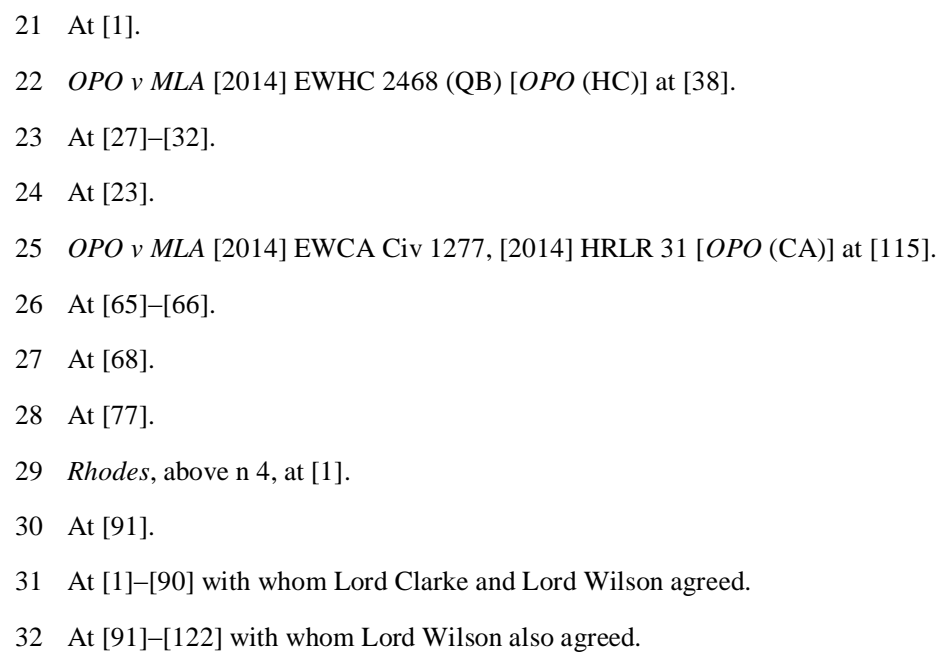




\section{Conduct element}

The Court held the first element requires "words or conduct directed at the claimant for which there is no justification or excuse". ${ }^{33}$ Interestingly, there is little discussion of what "directed at the claimant" actually means. Presumably, it is an attempt to narrow the scope of the tort to the very person or persons to whom the defendant attempted to inflict distress upon. The claimant may be part of a group (for example, where a person shouts "fire" in a cinema, when there is no fire, the address is to the audience, and any member might possibly be a claimant). ${ }^{34}$ Furthermore, not all actions that satisfy these requirements will necessarily be actionable; the first joint reasons stated it was unlikely that conduct that was not "deceptive, threatening or possibly abusive" would qualify. ${ }^{35}$ As discussed below, this requirement needs further clarification.

\section{Mental element}

The Court held that the requisite mental element was intention to cause "at least severe mental or emotional distress", ${ }^{36}$ a significantly lower threshold than intention to cause physical injury or a recognisable psychiatric illness. The first joint reasons also abolished the doctrine of imputed intent: that a defendant could be held liable for the natural and probable consequences of actions at law, while not subjectively intending them in fact. ${ }^{37} \mathrm{~A}$ court is now required to infer, as a matter of fact, whether the defendant actually intends to cause severe distress. Recklessness was deemed insufficient, chiefly because it would be problematic in practice and unduly widen the field of liability. ${ }^{38}$

Interestingly, Lord Neuberger noted that the intention requirement might "at first sight" seem too narrow, not least because it "might appear that it would not have caught the defendant in Wilkinson" as he merely intended a joke. ${ }^{39}$ However, he explained that the fact the statement was a joke is not necessarily inconsistent with an intention to upset. How, Lord Neuberger asked, could Downton not have intended to cause Wilkinson significant distress by falsely telling her that her husband had been seriously injured, given it was the purpose of the joke? ${ }^{40}$ With respect, this reasoning reverts back to a standard of imputed intention, because it is based on the consequences being "so obvious that the
33 At [88].
34 At [74].
35 At [77].
36 At [88].
37 At [81]-[82].
38 At [84]-[87].
39 At [112].
40 At [112]. 
perpetrator cannot realistically say that those consequences were unintended". ${ }^{41}$ So the issue of exactly how a Court is to infer intention as a matter of fact, without using probability or other notions incidental to imputing intention as a matter of law, is, problematically, left open in Rhodes.

\section{Consequence element}

The first joint reasons in Rhodes held that the consequence element required damage amounting to physical injury or a recognisable psychiatric illness. ${ }^{42}$ This conclusion was reached without a full discussion of why it was appropriate. Conversely, the second joint reasons held that, if an intention to cause severe distress is enough to establish the tort in principle, it was difficult to see why something more serious must be suffered before compensation can be recovered. ${ }^{43}$ Lord Neuberger also reasoned that the narrow restrictions on the tort's other elements provided a basis for holding severe distress should be the relevant damage threshold.

\section{Justifications}

The Supreme Court canvassed various justifications for conduct which might amount to IIED. These included the freedom to report the truth (with obvious exceptions, including where there is a duty to keep the information private) ${ }^{44}$ the public interest in disclosing information about one's history for others to learn, ${ }^{45}$ and where the law expressly gives positive authorisation.

\section{COMPARING THE NEW ZEALAND APPROACH}

\section{A Case Law}

New Zealand first adopted Wilkinson in Stevenson v Basham. ${ }^{46}$ Stevenson went to the Bashams' house and demanded that Mr Basham give up possession, lest he "burn him out". ${ }^{47}$ Mrs Basham, though not in the presence of Stevenson, was inside the house and heard his threats, causing her severe distress and a miscarriage. Herdman J held that "physical injury which is the consequence of a shock deliberately caused by a statement made by the defendant" is actionable, provided it was the "natural and direct consequence" of the shock. ${ }^{48}$
41 At [112].
42 At [73] and [88].
43 At [119].
44 At [77].
45 At [75]-[77].
46 Stevenson, above $\mathrm{n} 2$
47 At 227.
48 At 229. 
In Tucker v News Media Ownership (Tucker I), the claimant successfully relied on IIED as a novel basis for an interim injunction against publication of certain facts about his criminal history. ${ }^{49}$ This was upheld in the Court of Appeal, but that Court suggested the cause of action arose where "one who by extreme and outrageous conduct intentionally or recklessly causes severe emotional distress to another is liable for such emotional distress, provided that bodily harm results from it". ${ }^{50}$ At the substantive hearing, McGechan J refused to continue the injunction on the facts, but accepted IIED was part of New Zealand law. ${ }^{51}$

In Bradley $v$ Wingnut Films, Wingnut had produced a zombie "splatter" film featuring substantial amounts of blood and gore in a cemetery. ${ }^{52}$ Bradley's family burial plot appeared in the background for 14 seconds and was only directly involved at one point where an actor sat on the steps leading to the plot. Bradley brought proceedings under a number of grounds, including IIED. Gallen J held that IIED required a defendant to have "wilfully done an act calculated to cause physical harm to the plaintiff" and that the shock and illness were "natural consequences of the wrongful act". ${ }^{53}$ Something "more than a transient reaction" of emotional distress was required, however initially severe, and that reaction needed to translate into "something physical ... having a duration which [was] more than merely transient". ${ }^{54}$ Intention could be imputed, and the foreseeability of the consequences was also relevant. ${ }^{55}$ Gallen $\mathrm{J}$ held for the defendant on the basis the actions were not intended, were not directed against the claimant and the consequences were not foreseeable.

\section{B A Brief Comparison}

Since Bradley, IIED has not developed any further in New Zealand but has been mentioned in a few cases, the most recent being from 2013. ${ }^{56}$ The current formulation of the New Zealand tort is inconsistent with that of Rhodes in several respects. First, intention must be to cause physical harm or psychiatric illness, rather than severe distress. Secondly, intention may be imputed to the defendant based on the foreseeability of the consequences. Thirdly, in deciding whether the conduct was directed

49 Tucker v News Media Ownership Ltd HC Wellington CP477/86, 22 October 1986 [Tucker I] at 2.

50 News Media Ownership Ltd v Tucker CA172/86, 23 October 1986 [Tucker II] at 3 citing RFV Heuston and RS Chambers Salmond and Heuston on the Law of Torts (18th ed, Sweet \& Maxwell, London, 1981) at 198199.

51 Tucker v News Media Ownership Ltd [1986] 2 NZLR 716 (HC) [Tucker III] at 736.

52 Bradley, above n 3.

53 At 422 .

54 At 421 .

55 At 422

56 See $H v B$ HC Wellington CP7/97, 4 September 1998; Lv G (2002) 6 HRNZ 489 (DC); and Deliu v Hong [2013] NZHC 735. 
at the claimant, the defendant's intention is determinative. Fourthly, the discussion of foreseeability, and whether the consequences were natural, implies a question of remoteness. Finally, the consequence must be physical harm or a recognisable psychiatric illness (though this aspect is only inconsistent with the second joint reasons).

\section{REFORMING THE ELEMENTS}

Rhodes breathed new life into IIED, but the Court did not go far enough in reformulating its elements to ensure a viable future for the tort. This part of the article argues for further expansion of the elements outlined in Rhodes, without which, as explained later, the tort has little real future. A comparative evaluation between Rhodes and Bradley is provided. The author submits that, while some aspects of the New Zealand tort should be modified in line with the United Kingdom approach, the Rhodes version of the tort itself is also in need of reconsideration.

\section{A Conduct Element}

\section{Issues}

The lack of definition as to what "directed at the claimant" means within the conduct element is problematic. ${ }^{57}$ Both Rhodes and Bradley require the defendant's conduct, whether actions or statements, to be directed at the claimant, but they approach this question differently. ${ }^{58}$ Rhodes treats the question as one of fact, whereas Bradley and Stevenson treat it as a matter of law. The major difference between the United Kingdom and New Zealand approaches is that fewer claimants will be able to prove that the conduct was directed at them under the former approach than under the latter.

For example, in Stevenson, the claimant, "although not actually present", heard the defendant's threat to burn down the house and thereby suffered a "violent nervous shock" causing a miscarriage. ${ }^{59}$ It was found Stevenson knew Mrs Basham was inside the house, but it is doubtful whether she would succeed under the Rhodes formulation.

It is arguable that Stevenson addressed himself, or at least "should have known" he was addressing himself, to "any person who at the time might be an inmate of the house". ${ }^{60}$ Indeed, the first joint reasons in Rhodes stipulated the claimant may be part of a group whom the defendant addressed. ${ }^{61}$ However, as Herdman J held that the conduct was directed at Mrs Basham, Stevenson is arguably inconsistent with the findings in Rhodes because the book, though dedicated to OPO, was considered

57 Rhodes, above n 4, at [88].

58 At [74] and [88]; and Bradley, above n 3, at 422.

59 Stevenson, above $\mathrm{n} 2$, at 228.

60 At 228.

61 Rhodes, above n 4, at [74]. 
not to be directed at him. ${ }^{62}$ Furthermore, Herdman J wrongly mixed intention with direction in the sense that he held Stevenson's threats to be directed at Mrs Basham on the basis that Stevenson either knew or ought to have known (via imputed intention) that she was likely to suffer distress and injury. ${ }^{63}$ That direction is synonymous with intention was affirmed in Bradley.

\section{Reform}

Unfortunately, this leaves the law with two possible standards as to when conduct will be directed at the claimant. Stevenson and Bradley used imputed intention to find direction, meaning it is a question of law. Furthermore, even if those Courts found the defendant had the relevant subjective intention, it was determinative of the direction question. Conversely, Rhodes severs the conduct element from the mental element entirely, leaving direction as a question of fact. It is even possible to either distinguish or overrule Stevenson and Bradley in light of Rhodes, given the latter case abolished the doctrine of imputed intention. ${ }^{64}$

However, if direction is a matter of fact rather than a question of law, what does this mean and how will a claimant establish it? A broad contextual approach is probably the best. The test for direction should be whether the reasonable person in the position of the claimant would reasonably have believed that they were the target of the words or conduct in question. Relevant factors to take into account could include whether the claimant subjectively believed they were the addressee, whether the defendant's conduct was premeditated and whether the claimant was in the defendant's presence, actually or constructively, at the relevant time. Other policy-based considerations, such as the forum in which a statement is made, and whether the claimant was particularly vulnerable, ${ }^{65}$ might also be relevant. No factor should be determinative as a matter of law; Stevenson and Bradley should be overruled in this respect. This test is similar to the identification test for defamation in the sense it need be of and concerning the claimant. The claimant must prove that they were the target personally, or were referred to equally as part of a sufficiently delineated class or group. ${ }^{66}$ So, where it is alleged that conduct towards a group is to be understood as referring to every member of it, ${ }^{67}$ direction should be a question of fact and degree for the court.

This test is sufficiently restrictive to prevent overly-sensitive people, to whom the words or actions were clearly not addressed, from bringing claims. If a defendant were to post publicly on social media

62 At [74].

63 Stevenson, above $\mathrm{n} 2$, at 228

64 Rhodes, above n 4, at [81]-[82].

65 See the first joint reasons' discussion of the egg-shell skull principle in Rhodes, above $\mathrm{n}$ 4, at [87].

66 See Ursula Cheer "Defamation" in Todd (ed) The Law of Torts in New Zealand (7th ed, Thomson Reuters, Wellington, 2016) 839 at 866.

67 See for example Hyams v Peterson [1991] 3 NZLR 648 (CA) at 654-655 per Cooke P. 
that "all men are rapists", no person who saw that post would satisfy the direction requirement. While the claimant might be an involuntary addressee, a reasonable person would likely infer that they were not the target, or that the statement had no specific target. Importantly, the reasonable target test would likely produce the same conclusions on the direction questions in Stevenson and Bradley. The conduct element in Rhodes would also remain unchanged; OPO would not satisfy the reasonable target test: the book cannot have been directed at him.

\section{B Mental Element}

\section{Imputed intention}

The requisite fault standard in Rhodes is subjective intention to, at least, cause severe distress. Intention may be inferred from the facts, but cannot be imputed by law on the basis the outcome was a "natural and probable" consequence of the defendant's actions. ${ }^{68}$ Rhodes and Bradley are consistent in requiring intention as the fault standard, but the latter case held intention could be imputed and foreseeability was therefore important in that context. ${ }^{69}$ There are several reasons why imputed intention is not appropriate.

First, imputed intention wrongfully mixes two separate tort elements: a fault standard and remoteness. ${ }^{70}$ Using a remoteness test to justify finding a mental fault standard (such as intention), and then using that very finding to satisfy an element of remoteness at a later stage, leaves any consideration of either element devoid of any separate or logical meaning. ${ }^{71}$ So, regardless of whether the test for remoteness is reasonable foreseeability or naturalness and probability, ${ }^{72}$ if intention under the Wilkinson tort is imputed on the basis the consequences were foreseeable but remoteness is assessed later to consider whether the kind of harm inflicted ought to be recoverable, in what circumstances will it ever be in principle correct to conclude those consequences were too remote or not caused in law by the defendant? These elements ought to be kept separate; intention in relation to IIED ought only to be subjective intention inferred from all the facts. The Rhodes Court abolished the doctrine of imputed intention without discussing its conceptual difficulties, describing it as a "vestige of a previous age". ${ }^{73}$

68 Rhodes, above n 4, at [45] and [81].

69 Bradley, above n 3, at 422.

70 See Lunney, above n 15, at 183.

71 See Christopher Slade "Intentional Infliction of Mental Suffering: Reconsidering the Test for Liability" (2008) 34 Advoc Q 322 at 341. But see Rahemtulla v Vanfed Credit Union [1984] 3 WWR 296 (BCSC) at [51].

72 See Rhodes, above n 4, at [45] and Wilkinson, above n 1, at 59-60. See also Bill Atkin "Trespassing on Land" in Todd (ed) The Law of Torts in New Zealand (7th ed, Thomson Reuters, Wellington, 2016) 481 at 511-512, n 273.

73 Rhodes, above n 4, at [81]. 
Secondly, if the consequence element is to be reformed to allow recovery for severe distress falling short of a recognisable psychiatric illness, ${ }^{74}$ imputed intention "will not do". ${ }^{75}$ People regularly engage in conduct which is capable of distressing, humiliating or embarrassing without a subjective intention to cause severe distress. If intention could be imputed, a defendant might wrongly be held to have intended severe distress as a result of the probability of the actions causing it, when the only actual intention was to upset or to anger. The tort should not be invoked to allow recovery from a heated argument or harmless banter. ${ }^{76}$ Bradley ought to be overruled on the basis it allows imputed intention.

\section{Recklessness?}

The United States equivalent of Wilkinson imposes liability even where the defendant is reckless. ${ }^{77}$ Rhodes specifically rules out recklessness as a qualifying fault standard for the mental element. ${ }^{78}$ The first joint reasons held it would be problematic in practice because of the issues with the scope of liability for defendants. For example, a defendant in a heated dispute with a neighbour might make a deliberately insulting remark, intending it to be upsetting but not to cause severe distress. ${ }^{79}$ So, a recklessness standard might impose liability for disagreements part of ordinary life where society would not otherwise deem the defendant morally culpable. Therefore, Rhodes has a higher fault standard, but its United States counterpart has a higher threshold for the conduct element by requiring it to be "extreme or outrageous" ${ }^{80}$ Departing from the United States fault standard might be considered a quid pro quo for lack of this conduct requirement.

\section{Consequence Element}

The problem with courts treating Wilkinson as an action on the case, akin to an early form of negligence, has led judges to continue to require that the damage be physical harm or a recognisable psychiatric illness before compensation will flow, as is the case with negligently inflicted nervous shock. ${ }^{81}$ IIED should cover consequences of severe emotional distress. The Rhodes Court went "too

74 See Part V(C).

75 Wainwright, above n 16, at [45].

76 See Rhodes, above $\mathrm{n}$ 4, at [86] and [111].

77 American Law Institute Restatement (Third) of Torts: Liability for Physical and Emotional Harm (American Law Institute, Philadelphia, 2012) at $\$ 46$. See also R Fraker "Reformulating Outrage: a critical analysis of the problematic tort of IIED" (2008) $61 \mathrm{~V}$ and L Rev 983.

78 Rhodes, above n 4, at [87].

79 At [86].

80 American Law Institute, above $n 77$, at $\$ 46$.

81 van Soest v Residual Health Management Unit [2000] 1 NZLR 179 (CA). See also, in relation to IIED, Rhodes, above n 4, at [88] per Lady Hale and Lord Toulson; and Bradley, above n 3, at 421. 
far in narrowing the tort's scope" by requiring physical harm or a recognisable psychiatric illness. ${ }^{82}$ This requirement is "anachronistic" and sets the bar too high. ${ }^{83}$

\section{A coherent test}

The "trick for the law" is distinguishing between claims that warrant compensation, and those that do not, and articulating a "coherent basis upon which such a distinction can be made" ${ }^{84}$ For IIED, the distinction should be a question of severity, and the coherent basis should be whether the severe distress falls "plainly outside the range of ordinary human experience". ${ }^{85}$ The courts have the capacity to answer this question and to distinguish between "severe" and "mere" distress. ${ }^{86}$ It is a composite test. The following six reasons justify adopting this test and lowering the consequence threshold.

\section{New Zealand authority}

Though Bradley requires a claimant to establish something "more than a transient reaction, however initially severe" which must then "translate itself into something physical", 87 the suggestion that a lesser harm will suffice for recovery is not without precedent. Thomas $\mathbf{J}$ in his dissenting judgment in van Soest $v$ Residual Health Management Unit held that a claimant should be able to recover in negligence for mental suffering which is not a recognisable psychiatric illness but is "plainly outside the range of ordinary human experience". 88

While van Soest was a negligence case, Thomas J's arguments for a lower threshold are more compelling for IIED, given a claim in negligence is usually capped at what is reasonably foreseeable on the basis that the defendant's conduct was unwitting or careless. An intentional tort knows no such reasonable foreseeability cap. ${ }^{89}$ First, Thomas $\mathbf{J}$ suggests such a restriction is simply an "arbitrary" limitation measure that "can exclude some deserving complainants who suffered something which, while short of medically proven psychiatric harm, was considerably more serious and impacting than

82 Chris DL Hunt "Wilkinson v Downton Revisited" (2015) 74 CLJ 392 at 395.

83 Giller v Procopets [2008] VSCA 236, (2008) 24 VR 1 at [31] per Maxwell P. Contrast Slade, above n 71, at 328.

84 Anthony Gray "Wilkinson v Downton: New work for an old tort to do?" (2015) 23 Tort L Rev 127 at 140.

85 van Soest, above n 81, at [107].

86 See Thomas J's dissenting judgment in van Soest, above n 81.

87 Bradley, above n 3, at 421.

88 van Soest, above $\mathrm{n} 81$, at [107].

89 See Wilson v Pringle [1987] 1 QB 237 (CA) at 31; and Mayfair v Pears [1987] 1 NZLR 459 (CA). See also Stephen Todd "Trespass to the Person" in Todd (ed) The Law of Torts in New Zealand (7th ed, Thomson Reuters, Wellington, 2016) 101 at 105. 
commonplace grief or sorrow". ${ }^{90}$ The reasoning suggests that occasions arise where society would deem it sufficiently morally blameworthy to impose liability without psychiatric proof of mental illness.

Secondly, Thomas $\mathrm{J}$ reasoned that the law is capable of assessing mental distress. ${ }^{91}$ For example, breach of contract may lead to damages for "disappointment, the distress, the upset and frustration caused by the breach". 92 The courts are also "prepared to award damages for mental distress in claims based in tort where the distress is consequent upon the commission of some other wrong". ${ }^{93}$ This reasoning is highly relevant to IIED because the conduct of the defendant will nearly always be "wrong" in another sense: "deceptive, threatening, or possibly abusive". ${ }^{94}$ Requiring a double-fault standard provides added justification for allowing recovery for severe distress.

\section{Other jurisdictions' authorities}

Recovery for severe distress where the defendant intended this result has been hinted at in the United Kingdom. In Hunter v Canary Wharf, Lord Hoffmann saw "no reason why a tort of intention should be subject to the rule which excludes compensation for mere distress, inconvenience or discomfort in actions based on negligence". ${ }^{95}$ In Wainwright, he reserved his position but did not resile from that basic proposition given the "policy considerations" which made intentional torts different from negligence. In Rhodes, Lord Neuberger held that there was a "powerful case"—where intention to cause distress is an "essential ingredient" - that it should alone be enough for the claimant to show significant distress. ${ }^{96} \mathrm{He}$ reasoned that, "if an intention to cause the claimant significant distress is an ingredient of the tort and is enough to establish the tort in principle", it was difficult to see why something more than severe distress must be proved before the claimant could recover. ${ }^{97}$

Most United States' jurisdictions allow compensation for severe distress falling short of a recognisable psychiatric illness. ${ }^{98}$ "Severe emotional harm" is recoverable, and fears of indeterminate

90 van Soest, above n 81, at [101] per Thomas J.

91 Compare the majority judgment in van Soest, above $\mathrm{n} 81$.

92 See for example Jarvis v Swan Tours [1973] 1 QB 233 (CA).

93 van Soest, above n 81, at [104] per Thomas J.

94 Rhodes, above n 4, at [77]. Discussed below in Part V(C)(4).

95 Hunter v Canary Wharf Ltd [1997] AC 655 (HL) at 707.

96 Rhodes, above n 4, at [119].

97 At [119] (emphasis added).

98 American Law Institute, above n 77, at $§ 46$. See also Fraker, above n 77. 
liability have failed to materialise. ${ }^{99}$ The retention of the qualifier "severe" means a moment of fleeting distress is unlikely to qualify. ${ }^{100}$ There is also some suggestion in Australian authorities that, while recovery for mental suffering in negligence requires proof of a recognisable psychiatric illness, something "less than this will suffice in order to successfully bring a claim for [IIED]". ${ }^{101}$

\section{A filter}

The United States imposes an extra burden on claimants to prove the defendant's conduct was "extreme" or "outrageous". ${ }^{102}$ This requirement has a dual function. First, it acts as a liability filter, narrowing circumstances in which the defendant's actions can be tortious. Secondly, it represents a policy decision in the law that, to recover damages for severe distress falling short of a recognisable psychiatric illness, a defendant's actions must be doubly wrong in "some looser sense" rather just intending a particular type of harm. ${ }^{103}$

While acknowledging any filter based on a loose sense of moral wrong may be somewhat subjective, the Rhodes Court formulated a legal filter for the English tort, conceding that subjective assessments "cannot be avoided". ${ }^{104}$ The first joint reasons explained it was "difficult to envisage any circumstances" in which the defendant's actions were not "deceptive, threatening or possibly abusive" that could give rise to liability. ${ }^{105}$ The Court also required the conduct to be "without justification or reasonable excuse", 106 or at least "gratuitous". ${ }^{107}$

However, the filter's subjectivity and its lack of definition are problematic. If a broad interpretation is given, one might question whether it would exclude many cases at all, not least because Rhodes left open whether actions that were not deceptive or threatening, but were abusive, could give rise to

99 Geoffrey Christopher Rapp "Defense against Outrage and the Perils of Parasitic Torts" (2010) 45 Ga L Rev 107 at 136.

100 Gray, above n 84, at 141.

101 At 129, referring to Maxwell P in Giller, above $\mathrm{n} 83$.

102 See American Law Institute, above n 77, at $§ 46$.

103 Denise Réaume "The Role of Intention in the Tort in Wilkinson v Downton" in Jason W Neyers, Erika Chamberlain and Stephen GA Pitel (eds) Emerging Issues in Tort Law (Hart Publishing, Portland, 2007) 533 at 551 .

104 Rhodes, above n 4, at [110].

105 At [77].

106 At [74].

107 At [106]. 
liability. ${ }^{108}$ Lord Neuberger reasoned that neither description was ideal given "virtually every threat, untruth or insult can be said to be unjustified, inexcusable and gratuitous". 109

One further issue concerns situations where the information is true but nevertheless sufficiently threatening or abusive. For example, if a stepfather were to reveal to an adopted stepson: "Your real father is a murderer; I am going to tell everyone and I hope you feel humiliated". Assuming the statement is true, its threatening and abusive nature might give rise to liability under Rhodes. In situations like this, the claimant could also have difficulties establishing liability under other torts: invasion of privacy requires the information to be about the claimant, and a defence to defamation is that the information is true. Thus, the filter is not too restrictive as to deny a remedy for deserving claimants.

There are several reasons why the filter is a principled addition despite its perceived problems. ${ }^{110}$ First, it is justified if its underlying function is to restrict situations where claimants can recover for mental suffering falling short of a recognisable psychiatric illness. If, however, its underlying function were to justify the tort as a whole, it might be more problematic. Those reasons are canvassed in Rhodes in relation to IIED's potential impact on freedom of expression. ${ }^{111}$ Secondly, an element of subjectivity may be desirable as it will allow the courts to exclude frivolous or vexatious claims, and let the law "develop in a characteristic common law way ... on a case by case basis". ${ }^{112}$ Overall, while the liability filter might be a "challenging task", ${ }^{113}$ this is not a sufficient basis to deny its existence as an extra hurdle for a claimant in order to recover for severe distress.

\section{Other intentional torts}

Compensation for severe distress, and even lesser injury to feelings or dignity, are not unknown to the other intentional torts of trespass to the person: battery, assault and false imprisonment. ${ }^{114}$ They are not restricted to physical harm or psychiatric illness in the same way negligence is; they are wide enough to encompass conduct which "merely injures the dignity" of the claimant. ${ }^{115}$ For example,

108 At [77].

109 At [110].

110 But see Slade, above n 71, at 337-338.

111 Rhodes, above $\mathrm{n} 4$, at [77] and [110].

112 At [104].

113 Slade, above $\mathrm{n} 71$, at 323 .

114 See Todd, above n 89, at 103-105. But see PR Handford "Wilkinson v Downton and Acts Calculated to Cause Physical Harm" (1985) 16 UWA L Rev 31 at 34 for a discussion of these torts' differences from Wilkinson. Contrast Letang v Cooper [1965] 1 QB 232 (CA) at 239 per Lord Denning MR.

115 Handford, above n 114, at 34. 
battery is actionable per se and so any unlawful contact qualifies, ${ }^{116}$ making it clear the tort covers "offensive as well as harmful" contacts. ${ }^{117}$ Assault is exclusively concerned with causing mental anguish - its essence being the reasonable apprehension of an imminent battery, without the need for a battery. ${ }^{118}$ False imprisonment covers "purely dignitary injuries", ${ }^{119}$ given there is no minimum duration of imprisonment and damages may therefore be recovered for even token confinement. ${ }^{120}$ Indeed, many traditional cases might have fallen within the Wilkinson principle. ${ }^{121}$ It has been suggested that Wilkinson is a category of residual liability, created to fill the gap between the classic intentional torts and the unintentional torts. ${ }^{122}$ So, it is principled to suggest IIED can sit somewhere in between being actionable per se and requiring a recognisable psychiatric illness. That "somewhere" should be severe distress. Finally, while Deliu v Hong states Wilkinson is distinct from trespass to the person, ${ }^{123}$ this is only correct in so far that it does not neatly fit into that category. The tort's intentional nature provides sufficient similarity to trespass to the person that recovery for severe distress is justified.

\section{Intentional conduct}

Interestingly, while the first joint reasons noted that there were "good reasons of social policy" for the law to treat a person who intentionally caused damage to another more harshly than one who carelessly did so, it was still concluded that recovery cannot extend to distress not amounting to a recognisable psychiatric illness. ${ }^{124}$ Though this observation was made in the context of justifying IIED's independence from negligence, it is difficult to see why it could not equally apply to allowing recovery for severe distress. The level of moral culpability is higher when a defendant subjectively intends the consequence to result, compared to merely negligent conduct. This is also reflected by the intentional torts allowing recovery for all "direct" consequences of the defendant's acts, ${ }^{125}$ rather than

116 Todd, above n 89, at 107 and 109. See also Cole v Turner (1704) 6 Mod 149, 87 ER 907 (KB).

117 Handford, above n 114, at 34 .

118 See $T v H$ [1995] 3 NZLR 37 (CA) at 51; and Todd, above n 89, at 105.

119 Handford, above n 114, at 35. But see Meering v Grahame-White Aviation Co (1919) 122 LT 44 at 54 per Atkin LJ where liability is found even where the claimant is unconscious, meaning the injury can be to reputation rather than dignity.

120 See Walker v Commissioner of Police of the Metropolis [2014] EWCA Civ 897, [2015] 1 WLR 312.

121 See Bird v Holbrook (1828) 4 Bing 628; Smith v Selwyn [1914] 3 KB 98; and Bird v Jones (1845) 7 QB 742.

122 Handford, above n 114 , at 35.

123 Deliu, above n 56.

124 Rhodes, above n 4, at [42].

125 Wilson v Pringle, above n 89, at 31. See also Todd, above n 89, at 105. 
damage of the kind that was only "reasonably foreseeable". ${ }^{126}$ It is socially undesirable for a claimant who suffers severe distress outside the range of ordinary human experience - as a result of an intentional action by the defendant to cause that damage - to be without a remedy when that was the very purpose of the defendant's actions. Why should anyone be without legal recourse for behaviour that causes them significant mental anguish? The substitution of imputed intention by subjective intention also means that the defendant actually has a malicious motive to cause harm, and is therefore more morally answerable for the consequences than where the law imputes the necessary intent.

\section{Availability of injunctions}

In Rhodes, OPO was unsuccessful in gaining an interim injunction restraining publication of Instrumental. ${ }^{127}$ Had he been successful, the order sought would have had the aim of preventing psychiatric illness. It is likely that, in similar cases involving potential publication of information or threatening conduct, claimants will seek a similar remedy. However, if the consequence element requires physical harm or a recognisable psychiatric illness, claimants would have a difficult legal hurdle to clear, one that may be too burdensome. As the relevant threshold for a quia timet injunction is "a strong probability of grave damage", ${ }^{128}$ claimants would need to produce compelling evidence that a particular psychiatric illness will be suffered. ${ }^{129}$ Despite the availability of expert medical evidence, it is difficult to predict with this level of certainty that such a consequence will result. If severe distress were the necessary harm, the prospects of success would be better. Vulnerable claimants, such as children or the mentally disabled, should not be denied quia timet relief and suffer harm waiting for a regular prohibitive injunction to stop the defendant's conduct after the onset of psychiatric illness.

\section{Summary}

Overall, the Rhodes elements provide a good basis for the tort's continued survival, but they do not go far enough. The proposed reforms - particularly the clarification of the conduct element and the lowering of the consequence threshold - offer a more secure alternative to the Rhodes formulation. However, IIED's future rests on more than just its internal structure. Its relationship with other torts, especially negligence and privacy, and how it fits into the wider tort landscape are also important.

126 Overseas Tankship (UK) Ltd v Morts Dock \& Engineering Co Ltd (The Wagon Mound (No 1)) [1961] AC 388 (PC).

127 Rhodes, above $\mathrm{n}$ 4, at [90].

128 Bill Atkin "Remedies" in Todd (ed) The Law of Torts in New Zealand (7th ed, Thomson Reuters, Wellington, 2016) 1305 at 1349-1350. See also Grocott v Ayson [1975] 2 NZLR 586 (SC).

129 See Atkin, above n 128, at 1349. See also Attorney-General (Canada) v Ritchie Contracting \& Supply Co Ltd [1919] AC 999 (PC). 


\section{SUBSUMPTION INTO NEGLIGENCE?}

Wilkinson's place in tort law has been characterised by a long-standing debate as to whether it should be subsumed into negligence. ${ }^{130}$ However, there are conceptual and policy-based flaws in the subsumption argument. The article provides five reasons that justify IIED's independent existence and argues that negligence will not do "just as well". ${ }^{131}$

\section{A Lack of Precedent}

First, there is no actual authority for holding the fault standard in Wilkinson was negligence. As the name suggests, IIED is an intentional tort. ${ }^{132}$ Intention in the Wilkinson context means intention to bring about some harmful or wrongful consequence, rather than a mere deliberate act or statement. ${ }^{133}$ Wright $\mathbf{J}$ held the defendant's actions had to be "wilful" while also distinguishing Victorian Railways $v$ Coultas, ${ }^{134}$ a Privy Council case on negligently inflicted nervous shock that, though involving a deliberate act, did not involve "any element of wilful wrong". ${ }^{135}$ If Coultas was distinguished on the basis of wilfulness, there must be more to wilfulness than a deliberate act, as the defendant in Coultas acted deliberately but negligently. ${ }^{136}$

Further, it is implausible to suggest Wright J used wilfulness or intention as "code for negligence" simply by looking to the facts. ${ }^{137}$ Réaume questions whether there is a "substantial risk" that telling someone her husband has been "bashed up" will result in physical harm resulting from shock. ${ }^{138}$ It is possible, but not likely. Indeed, if the outcome was reasonably foreseeable to Downton (and intent was not imputed), why would later cases after the dawn of modern negligence continue to use this language ${ }^{139}$ In New Zealand, Bradley specifically states "that the tort depends upon the actions concerned being intentional", holding that "no doubt that distinguishes it from ... negligence". ${ }^{140}$ So, on the basis of the reasoning in Wilkinson itself, there was a clear distinction made between a

130 See for example Wainwright, above n 16, at [41].

131 At [41].

132 But see Deliu, above n 56, at [91].

133 Réaume, above n 103, at 538.

134 Victorian Railways Commissioners v Coultas (1888) 13 AC 222 (PC).

135 Wilkinson, above n 1, at 60 .

136 Réaume, above n 103, at 538.

137 At 540.

138 At 540

139 Donoghue v Stevenson [1932] AC 562 (HL).

140 Bradley, above n 3, at 422. 
deliberate but careless act which brought about an unreasonable risk of harm (negligence) and an intentional act done with the specific purpose of committing some harm or other wrong (Wilkinson).

\section{B Remoteness}

An intention to cause harm imports a higher level of moral culpability than merely inadvertent conduct. Tort law responds to this distinction by imposing a threshold for the amount of damages the defendant will be liable for, dependent on the type of tort and the defendant's state of mind. This is known as remoteness. The underlying question is: to what extent should the defendant be liable for the consequences of the tortious actions? In the case of intentional torts and, it is submitted, IIED, the relevant remoteness standard is one of directness or "all natural and probable consequences" of the defendant's conduct. ${ }^{141}$ In negligence, the defendant will only be liable for consequences that were of a kind that was reasonably foreseeable. ${ }^{142}$ Subsuming IIED into negligence would mean that a defendant would be liable only for consequences up to this threshold, which is undesirable if the defendant actually intended the harm to occur. The first joint reasons specifically held that there were "good reasons of social policy" for the law to treat a person who deliberately does something which causes another harm by telling them a false story more harshly than one who carelessly passes on false information. ${ }^{143}$

There may be situations where the consequences of the defendant's acts could be said to be direct but not reasonably foreseeable; so if IIED were to be subsumed into negligence, deserving claimants might go uncompensated. Réaume notes a negligence analysis, in cases where "serious mental health problems triggered by the defendant's abusive behaviour" linger for years, will "require courts to decide how much of this was actually foreseeable". ${ }^{144}$ "Undoubtedly", some previously successful claimants would "fall afoul of a foreseeability requirement". ${ }^{145}$ For example, if Wilkinson were to be so shocked by Downton's joke that she collapsed and entered into a coma, can it be said that this kind of consequence was reasonably foreseeable? Probably not. What can be said, however, is that it was a "direct" result of Downton's statement. Indeed, while Rhodes held that, in relation to IIED, a "loose analogy may be drawn with the 'egg shell skull' doctrine", ${ }^{146}$ it has long been appreciated that doctrine "fits uneasily within the negligence principle". ${ }^{147}$

141 See Mayfair, above n 89; and Wilson, above n 89, at 247. See also Todd, above n 89, at 105

142 The Wagon Mound (No 1), above n 126.

143 Rhodes, above n 4, at [42].

144 Réaume, above n 103, at 553.

145 At 553

146 Rhodes, above n 4, at [87].

147 Réaume, above n 103, at 553. 


\section{Remedies}

Rhodes, Bradley and Tucker I all involved applications for an injunction, relying on the Wilkinson action. None of these cases questioned the availability of injunctive relief under IIED. If, however, IIED were to be subsumed into negligence, claimants would not be able to seek an injunction to prevent harmful conduct outside the tort(s) of privacy. Claimants should be able to seek an injunction to prevent severe distress. The Rhodes Court did not deny the injunction for want of jurisdiction to grant one. Rather, the tort was simply not made out. ${ }^{148}$ In an appropriate case, an injunction may be granted. For example, in the recent "Wicked Campers" campaign, offensive slogans and cartoons encouraging drug use and sexual violence were painted on the sides of vans for recreational hire. ${ }^{149}$ Provided a claimant could establish the other elements of the tort, ${ }^{150}$ an injunction would be an appropriate remedy. ${ }^{151}$

\section{The Duty of Care}

The claimant in Rhodes brought proceedings in negligence and under IIED. At first instance, Bean $\mathrm{J}$ held that there was no duty of care owed because "parental duties of care towards their children only arose when they were acting in specific capacities such as occupier, driver or supervisor of small children". ${ }^{152}$ On appeal, the Court held the foreseeability and proximity elements of the duty applied, but that it would not be "fair, just and reasonable" to impose a blanket duty of care upon the parental role. 153

Whether or not the conclusions on negligence are correct, there is no equivalent duty under the IIED tort. If it were to be subsumed into negligence, there would be difficulties for claimants who would have to prove a duty existed. There will be scenarios, like Rhodes, where a duty cannot be established. Furthermore, the duty of care is more relevant to cases where the defendant's conduct is inadvertent, rather than intentional. Its purpose is to restrict potential claimants from bringing actions against persons who, for proximity and policy reasons, cannot be said to owe a duty to not act negligently.

148 Rhodes, above n 4, at [74]-[75] and [77]-[78].

149 See David Fisher "Wicked Campers - 100\% offensive" The New Zealand Herald (online ed, Auckland, 20 March 2016); and Clare Kermond "Why I've gone to war against Wicked Campers" The Timaru Herald (online ed, Timaru, 11 May 2016).

150 For example, establishing the conduct element and direction requirement by satisfying the reasonable target test may be difficult in this scenario.

151 See Part V(C)(7) and Part VII(A)(2) for further discussion on injunctive relief.

152 Carol Brennan "Wilkinson v Downton as a novel basis for an interim injunction against publication" (2015) $31 \mathrm{PN} 33$ at 34.

153 See $O P O(\mathrm{CA})$, above n 25, at [48]-[57]; and Brennan, above n 152, at 34. 


\section{E Recoverable Harm}

The law of negligence does not allow recovery for severe distress falling short of a recognisable psychiatric illness. ${ }^{154}$ This should not be the rule for IIED. ${ }^{155}$ If the tort were subsumed into negligence, claimants will be denied compensation.

\section{PRIVACY AND IIED}

New Zealand courts recognise two torts of privacy: publication of private information, the tort in Hosking $v$ Runting: ${ }^{156}$ and intrusion into seclusion, the tort in $C v$ Holland. ${ }^{157}$ The privacy field is developing rapidly in New Zealand, but is still an uncertain area of tort law. ${ }^{158}$ The common law of invasion of privacy in New Zealand has its roots in Wilkinson, ${ }^{159}$ and features many conceptual similarities. The article analyses the relationship between, and the impact of, the evolving privacy torts on IIED. It then argues that IIED has a legitimate role overlapping with, but independent from, these torts. Hosking and Holland are not suited to subsume the Wilkinson action, especially given the narrower purpose of privacy torts and their limitations.

\section{A The Relationship Between Privacy and Wilkinson}

\section{Mutually protected interests}

One might initially question whether there is any relevant relationship between IIED and the privacy torts, because the facts in Wilkinson do not neatly fit under either Hosking or Holland. However, the primary interface between the two fields lies in their mutual protection of certain sociolegal interests. Both protect the individual from intrusive and invasive conduct jeopardising legal

154 van Soest, above n 81, at [24] per Blanchard J for the majority. See also McLoughlin v O'Brien [1983] 1 AC 410 (HL) at 416. But see Swan v Williams (Demolition) Pty Ltd (1987) 9 NSWLR 172 (CA).

155 See Bettel v Yim (1978) 88 DLR (3d) 543, (1978) 5 CCLT 66 (Co Ct) at [31] for discussion about the intentional/negligence distinction as to recoverable harm. See also Giller, above n 83, per Maxwell P.

156 Hosking v Runting [2005] 1 NZLR 1 (CA).

157 C v Holland [2012] NZHC 2155, [2012] 3 NZLR 672.

158 See Stephen Todd "Tortious Intrusions Upon Solitude and Seclusion: A Report from New Zealand" (2015) 27 SAcLJ 731 at 736.

159 See Part VII(A)(2). 
rights to personal safety, ${ }^{160}$ dignity, ${ }^{161}$ autonomy, ${ }^{162}$ and mental well-being. ${ }^{163}$ So, there is room for the argument that privacy, in its current and developing form, might render IIED unnecessary, especially on the intrusion tort front. Indeed, given that situations like Rhodes might be covered by the Hosking or Holland torts, some academics have questioned the continued usefulness of IIED, implying that it is being subsumed. ${ }^{164}$ However, it is wrong to suggest that, simply because one tort protects certain interests or rights, another tort is useless or should be relegated to the common law graveyard. Tort is a complex matrix of causes of action, which often overlap and cover a spectrum of interests. Furthermore, the privacy torts cover a narrower area of tort law, so sounding the death knell for Wilkinson with privacy as its executioner would likely leave deserving claimants uncompensated. This issue is discussed below.

\section{Injunctive relief and truthfulness}

Another reason for the overlap between the two fields is because IIED, in New Zealand at least, may be considered the "parent" tort of the torts of privacy. For example, Tucker $I^{165}$ was primarily a privacy case of intentional disclosure of private information which might have caused emotional distress, rather than an IIED case arising from an intention to cause mental suffering. Nevertheless, the Court issued an interim injunction relying on Wilkinson. Jeffries J noted a tort of privacy was a "natural progression of the tort of intentional infliction of emotional distress and in accordance with the renowned ability of the common law to provide a remedy for a wrong". ${ }^{166}$ Currently, therefore, IIED and privacy are both able to provide injunctive relief for breach of these interests. ${ }^{167}$ Furthermore, if it is accepted that IIED is actionable in cases where the information is true, but sufficiently threatening or abusive, then disclosure of truthful information causing severe distress is

160 See Wilkinson, above n 1, at 59; and Hosking, above n 156, at [22] per Gault P and Blanchard J and at [260] per Tipping J.

161 See Rhodes, above n 4, at [92] per Lord Neuberger and Lord Wilson; and Brooker v Police [2007] NZSC 30, [2007] 3 NZLR 91 at [123] as cited in Holland, above n 157, at [27]. See also Nicole Moreham "Why is Privacy Important? Privacy, Dignity and Development of the New Zealand Breach of Privacy Tort" in Jeremy Finn and Stephen Todd (eds) Law, Liberty, Legislation (LexisNexis, Wellington, 2008) 231 at 236.

162 See Hosking, above n 156, at [22] per Gault P and Blanchard J and at [239] per Tipping J; and Holland, above n 157, at [65]. See also Thomas Levy McKenzie "The New Intrusion Tort: The News Media Exposed?" (2014) 45 VUWLR 79 at $80-82$.

163 See Hosking, above n 156, at [239] per Tipping J. See also McKenzie, above n 162, at 82; and Peter Handford "Wilkinson v Downton: Pathways to the future?" (2012) 20 Tort L Rev 145 at 148

164 Todd, above n 158, at 736-738.

165 Tucker I, above n 49.

166 At 6.

167 See for example Australian Broadcasting Corporation v Lenah Game Meats Pty Ltd [2001] HCA 63, (2001) 208 CLR 199 at [256] per Gummow and Hayne JJ. 
another similarity between the two fields. Had Rhodes written about OPO's Asperger's syndrome, dyspraxia or dysgraphia in an abusive way and intended to cause severe distress, OPO might have had more chance of success in gaining an injunction under either the second joint reasons in Rhodes or Hosking.

\section{$B$ The Case for IIED's Independence}

There are conceptual and policy-based difficulties with both of the torts of privacy subsuming IIED. Can a parent tort be subsumed by its child? Should we allow privacy to do IIED's work even if claimants go uncompensated? This part of the article analyses these issues, concluding that subsumption or abolition of IIED by the common law of privacy is undesirable.

\section{The "highly offensive" hurdle}

In Rhodes, the proceeding under the English privacy tort of misuse of private information was struck out at first instance because the information not about OPO. ${ }^{168}$ This conclusion was upheld on appeal. ${ }^{169} \mathrm{Had}$ the opposite been the case, an action under this tort might have gone to trial, so there is an area of overlap between the two fields. If the proceedings were brought in New Zealand and if the information was about OPO, the claimant would need to prove that the publication would be "highly offensive to a reasonable person". ${ }^{170}$ This is a formidable hurdle, one, it is submitted, that is too high for the ordinary IIED claimant to clear where, otherwise, a remedy might be expected.

For example, if a bitter ex-husband were to reveal that his ex-wife had a particularly embarrassing health condition at her second wedding, intending severe distress, it is unlikely she would recover under Hosking. It is probably embarrassing, humiliating and potentially severely emotionally distressing, but can it really be said to be highly offensive to the reasonable person? Probably not. Alternatively, if the ex-husband were to film the ex-wife kissing her new husband in the backyard of their home, the Holland tort would again require that this intrusion be highly offensive to the reasonable person, ${ }^{171}$ something the ex-wife would likely have difficulty in proving.

Conversely, an IIED tort requiring at least severe distress would have a reasonable prospect of success, especially if intention to cause distress need not be the defendant's sole purpose. ${ }^{172}$ Presumably, the Rhodes filter - that the conduct be deceptive, threatening or abusive - is also easier to satisfy than a "highly offensive" requirement. Therefore, deserving claimants who would otherwise

168 OPO (HC), above n 22, at [23].

$169 O P O(\mathrm{CA})$, above n 25, at [35] and [47].

170 Hosking, above n 156, at [127].

171 Holland, above n 157, at [94].

172 See Rhodes, above n 4, at [114]. 
be able to maintain a successful action could be left without a remedy if the Hosking or Holland torts subsumed IIED.

\section{Damage}

A major difference between IIED and the privacy torts is that the latter group are actionable per se, whereas the former tort requires proof of damage. The Hosking and Holland torts protect against, inter alia, harms "in the nature of humiliation and distress" and are "not concerned with issues of whether there need be recognised psychiatric harm". ${ }^{173}$ In this respect, they are partially consistent with Rhodes in that distressing consequences are compensatable, provided they materialise into a recognisable psychiatric illness, ${ }^{174}$ or, as per the second joint reasons, severe distress. ${ }^{175}$ While "the question remains whether [IIED] ... might cover intrusive conduct causing mental upset", ${ }^{176}$ thereby offering a concurrent claim with the Holland tort if the differing elements are satisfied, it is submitted that leaving the privacy torts to do IIED's work on their own is undesirable.

IIED should not be, and never has been, actionable per se. The essence of Wilkinson is that some damage is sustained; ${ }^{177}$ this article argues the appropriate threshold for mental suffering should be severe distress. The reason for the damage requirement is that claimants should not be entitled to compensation for the mere vicissitudes of life — harmless practical jokes or heated arguments - that every person is subject to. ${ }^{178}$ So while it is acknowledged that protection of intangible interests such as dignity or freedom from intrusion is a part of the Wilkinson action, damage is a core requirement. It would, therefore, be conceptually illegitimate and undesirable from a policy perspective to abolish IIED in light of the developments in Hosking and Holland.

Finally, IIED's mental element could provide a point of difference in terms of damages recoverable. The Rhodes formulation distinguishes itself from Hosking on the basis the conduct must be intended to cause severe distress, whereas liability under the publicity tort need not stem from an intention to cause harm. So, while severe distress may be compensatable under either IIED (as proposed) or Hosking, there might be a difference in assessing the quantum of damages where such consequences were intended (IIED) compared to cases that do not feature this intention but result in

173 Hosking, above n 156, at [128] per Gault P and Blanchard J.

174 Rhodes, above $\mathrm{n}$ 4, at [88] per Lady Hale and Lord Toulson.

175 Rhodes, above n 4, at [119] per Lord Neuberger.

176 Todd, above n 158 , at 736 .

177 Wilkinson, above n 1, at 59; Stevenson, above n 2, at 230 and 232; Bradley, above n 3, at 421-422; and Rhodes, above n 4, at [88] and [119]. See also Penelope Watson "Searching the Overfull and Cluttered Shelves: Wilkinson v Downton Rediscovered" (2004) 23 U Tas L R 264 at 271.

178 See Rhodes, above n 4, at [86] and [111]. See also Rahemtulla, above n 71; and High Parklane Consulting Inc v Royal Group Technologies Ltd [2007] OJ 107 (QL) at [36]. 
the same consequence (Hosking). Wilkinson's touchstone has always been unjustified infringement with personal safety that causes damage, ${ }^{179}$ rather than just a dignitary tort akin to Hosking or Holland. Indeed, Todd has argued that the Wilkinson line of authority probably has "little or no part to play in developing a new rule of liability in respect of intrusive conduct", citing conceptual difficulties with merging the two fields of tort law and identifying the Rhodes hurdles as difficult to surmount. ${ }^{180}$

\section{CONCLUSION}

Rhodes is a welcome improvement to the law of IIED, and the rule in Wilkinson has been effectively reincarnated into a newly defined tort. However, it does not go far enough to secure IIED's future as a stand-alone cause of action, especially given the ever-expanding tort of negligence. The conduct element requires clarification; the consequence element requires reform to allow recovery for severe distress. It is no longer tenable, doctrinally or policy-wise, to require claimants to suffer physical injury or a recognisable psychiatric illness. If New Zealand tort law is to provide fair compensation to deserving claimants in the IIED context, an appellate court will need to overrule current authority and depart from the first joint reasons in Rhodes. While it is no easy task for the common law to make a significant leap forward, the social milieu is markedly different from 1897 , and the legal and policy reasons highlighted in the article justify further reform.

179 Wilkinson, above n 1, at 59 .

180 Todd, above n 158 , at 738 . 
